\title{
Н.В.Анацька,
}

кандидат філософських наук, старший викладач кафедри філософії НТУУ«КПІ імені Ігоря Сікорського»

\section{ЖИТТЕВО-ЦІННІСНІ ОРІЄНТАЦІЇ В СИСТЕМІ ЕКОЛОГІЧНОЇ ОСВІТИ}

Сьогодення українських реалій характеризується кризою екологічної культури, яка зумовлена низьким рівнем екологічної освіти й екологічної свідомості більшої частини населення. Отже, необхідна відповідь щодо протидії цим руйнівним для України аспектам. Тому, надзвичайно актуальною постає проблема збереження природної та культурної спадщини. За таких обставин потрібно через екологічну освіту віднайти засоби вирішення екологічних проблем сучасного суспільства. Разом з тим слід показати, як формуються життєвоціннісні орієнтації в процесі освіти, враховуючи те, що освіта значною мірою визначає майбутнє суспільства, його розвиток і дає необхідні знання щодо розуміння і вирішення сучасних глобальних проблем. Окрім того, «Агресивний глобалізм спричиняє появу нових особистостей, які повністю сприйняли технократичні, меркантильні цінності, - далекі від гуманістичних, - що створює небезпеку для цивілізації загалом. Бурхливий розвиток цивілізації (освоєння космосу, інформаційна революція, виникнення мікропроцесорної технології тощо), водночас передчуття екологічної, а то й антропологічної кризи стимулюють в особистості усвідомлення єдності людства як планетарної спільноти» $[2,5]$.

Умови захисту і збереження природи вимагають від суспільства i кожної людини переорієнтацію своїх життєвих цінностей. А це означає переорієнтація 3 «мати» на «бути», на збереження природи як абсолютної цінності життя. У всіх сферах відбуваються зміни життєвоціннісних орієнтацій, або їх уточнення відповідно до завдань дня.

За наявних умов про надзвичайну значимість екологічної освіти йдеться у працях українських і зарубіжних науковців, соціальнофілософські аспекти екологічної освіти висвітлені у роботах В.Андрущенка, О.Базалука, Г.Білявського, Т.Гардашук, М.Голубця, Ф.Канака, М.Кисельова, В.Крисаченка, К.Корсака, О.Салтовського, З.Самчука, Т. Тимочко, А. Толстоухова та інших.

Ціннісні засади екологічної етики, етики відповідальності розкри- 
вають наукові дослідження В.Гура, А.Срмоленка, Г.Йонаса, С.Кримського, К.Майєра-Абіха, Г.Марушевського, Р.Неша, Н.Хамітова та інших.

Осмисленню глобальних екологічних проблем, екологічної культури присвячені роботи Б.Гаврилишина, М.Поповича, Л.Сидоренко, М. Тарасенка, В.Хилька, В.Шинкарука, Л.Юрченка та інших.

Формування життєво-ціннісних орієнтацій у системі «людинаприрода» досліджують Г.Берегова, В.Борейко, В.Вернадський, Р.Інглегард, Р.Неш, О. Леопольд, Т.Чорноштан, А.Швайцер та інші. У своїх працях вони роблять багато змістовних висновків щодо формування життєво-ціннісних орієнтацій в системі екологічної освіти, хоча це питання до сьогодні є не повністю вивченим і продовжує бути предметом наукових досліджень.

Мета дослідження полягає у необхідності нових пошуків життєвоціннісних орієнтацій та морально-етичних норм регуляції відносин суспільства й природи, становленні моральних засад гармонізації стосунків людини 3 природою, які базуються на абсолютній цінності життя. Відповідно до поставленої мети визначено наступне завдання: розкрити сутність і змістовні характеристики екологічної освіти як носія гуманістичних життєво-ціннісних орієнтацій.

Значущим внутрішнім компонентом моральної свідомості людини, який надає саме духовної змістовності системі ії мотивацій, стають ціннісні орієнтації. Обираючи певні життєві ціннісні орієнтації, людина тим самим формує стиль своєї поведінки, а отже життєдіяльності. Мотивація відповідає на запитання для чого?, чому? людина зробила певний вибір, а ціннісна орієнтація показує те, заради чого зроблено цей вибір, яка життєва мета базова в іiі практичній діяльності, тобто цінності наповнюють смислом існування самої людини, а отже духовно іiі відтворюють. «Ціннісні орієнтації не завжди реалізуються безпосередньо, вони - лише базисні світоглядні критерії прийняття особистістю важливих рішень. Вони розгортаються в цілях, ідеалах, інтересах, намірах, принципах, переконаннях і є утвореннями ідейно-цільового формату, своєрідною генеральною лінією життя людини. Свій вияв вони знаходять у вербальних програмах дій і в реальній поведінці людей» [3, 33]. Ці цінності ще називають «смисложиттєвими», коли це стосується безпосередньо особистості, тобто метою життя є її самоствердження, а отже самоздійснення. Життєво-ціннісні орієнтації несуть відповідальність за процес пристосування внутрішнього світу особистості до реалій навколишнього світу. «Вони утворюють складну багаторівневу 
ієрархічну систему, посідаючи проміжне положення між мотиваційною сферою та системою особистісних смислів. Відповідно, ціннісні орієнтації виконують двоїсті функції. 3 одного боку, система ціннісних орієнтацій виступає в якості найвищого контрольного органу регуляції усіх збудників активності людини, визначаючи прийнятні способи їхньої реалізації. 3 іншого, - в якості внутрішнього джерела життєвих цілей людини, виражаючи те, що є найважливішим і володіє найбільшим особистісним смислом. Таким чином, система ціннісних орієнтацій $є$ важливим інструментом саморозвитку і особистісного вдосконалення, яка визначає і водночас спрямовує способи такого самоздійснення» $[3,33]$.

Особистість через свій внутрішній світ морально переживає свої дії, вчинки на основі цінностей, зокрема таких, як людська гідність, справедливість, свобода тощо, створюючи при цьому у своїй свідомості певні моральні критерії поведінки. Ціннісні орієнтації, які становлять внутрішню складову свідомості, а також самосвідомості людини, відіграють значну роль у спрямованості ії життєвоціннісних орієнтацій, тому що, орієнтуючи на них свої вчинки, особистість в результаті утверджує своє свідоме ставлення до сущого і належного. Очевидно, що в теоретичному плані використання етичних настанов «...пов'язане 3 необхідністю надання морально-ціннісним орієнтаціям як масштабам діяльності характеристик достовірного знання, що означає досягнення їх єдності зі знанням дійсних реалій життєдіяльності людини і суспільства. Інакше кажучи, «основні цінності» належало б включити в процес пізнання, в якому б було досягнуто єдність знання про суще і належне» $[6,93]$. Відповідно до цього пізнання, яке $\epsilon$ активністю людського розуму і здатне отримувати науково вивірені етичні та інші знання, повинно з'ясувати норми морального належного, які необхідні сучасному суспільству, де відбуваються якісні зміни глобального характеру. «Якісні зміни в суспільстві пов'язані насамперед зі зміною консенсусу щодо цінностей, з порушенням рівноваги в цьому аспекті. Для відтворення рівноваги необхідно переглянути діапазон (часто) та ієрархію (завжди) ціннісних пріоритетів під кутом зору їхньої відповідності новим смисловим критеріям та ідеалам, які слугують цільовими орієнтирами і життєдіяльнісними взірцями» [3, 61].

Життєво-ціннісні орієнтації існують у вигляді складної системної ієрархії, де кожна цінність займає свою певну нішу. 3 цього погляду зростає значення екологічних цінностей. «Актуальність 
екологічних цінностей і загалом екологічної проблематики, а отже й нагальна потреба ії грунтовної концептуальної розробки, в умовах сучасної України зумовлена двоєдиною причиною: по-перше, критичною екологічною ситуацією, в якій опинилися чимало українських регіонів, по-друге, підлеглістю України глобальним тенденціям в екології, які додатково підсилюють кризовість української симптоматики і перспективістики» $[3,61]$, а це в свою чергу зумовлює значне розширення сфери морально-екологічної регуляції, яка обстоює екологічну зорієнтованість особистості, необхідність екологічного типу поведінки й діяльності. «...звертаючись до теми місця цінностей у структурі освіти, слід зауважити, що освіта завжди відтворює (з точки зору суспільства) та формує (з точки зору учнів) певний тип світогляду. Саме через світогляд, а не у чистому теоретичному вигляді учень засвоює певну систему цінностей. Формування світогляду є завданням виховання» $[13,11]$, саме тому життєво-ціннісні орієнтації є головною проблемою екологічного виховання. «Цінність виникає, тобто стає реальною лише тоді, коли людина іï обирає як свій життєвий орієнтир. У життєвих виявах людини, яка керується обраною цінністю, остання стає зримою та очевидною для інших людей, слугує певним зразком та унаочненням, що віддзеркалює й демонструє іiі життєві принципи та позиції» $[11,441]$. У цьому контексті як складова екологічної освіти екологічне виховання формує життєво-ціннісні орієнтації сучасної людини. Під час розкриття цього питання важливо зрозуміти, що при цьому екологічне виховання передбачає високий рівень знань, який сприяв би формуванню екологічної свідомості, тобто усвідомленню екологічної цілісності природи, розумінню єдності людини та природи. Екологічні знання мають силу лише тоді, коли в результаті виховання стають екологічними переконаннями.

У заключному акті Гельсінської конференції з безпеки і співробітництва в Європі, яка відбулася в 1975 році, наголошувалося, що «Успіх політики в галузі навколишнього середовища передбачає те, що всі групи населення і суспільні сили мають усвідомлювати свою відповідальність за збереження і покращення оточуючого середовища, а це потребує постійного і ретельного виховання» $[4,6]$. Ці питання підпорядковані тому, щоб суспільство було відповідальним за екологічні наслідки науково-технічного прогресу і щоб цьому процесу надати соціально-гуманістичного спрямування і саме через екологічні знання, які трансформуються в процесі освіти 
в екологічне виховання. Самі по собі екологічні знання не дають бажаного результату, тут необхідний взаємозв'язок знання і виховання. Знання дають уявлення про людину, про природу, про їх взаємодію, а виховання має показати в цій взаємодії, яка має утилітарну мету, щоб задовольнити потребу людини, ставлення людини із знанням справи до природи, до самої дії із розумінням екологічного й морального аспекту цінностей буття.

Такий підхід показує актуальність екологічного знання, екологічної освіти й виховання, довгий час якими займалася переважно педагогіка, і був поширений термін «природоохоронна освіта», а згодом у практиці з'явився ще один термін - «екологічне виховання», які довгий час вважалися рівнозначними. 3 часом з'являється новий підхід, оскільки сучасне суспільство живе в новій екологічній, соціальній, економічній і культурній ситуації, виникають нові світоглядні, методологічні проблеми стосовно сфери екологічної освіти, які раніше не піднімались. «Їх повноцінне вирішення не під силу жодній формі суспільної свідомості, окрім філософії. Якщо метою і змістом освіти є формування особистості громадянина, що передбачає всебічну розвиненість, гармонійність, високу відповідальність та інші позитивні якості, то зрозумілою є актуальність філософії освіти» $[10,275]$. Це засвідчує, що екологічне виховання $\epsilon$ прерогативою екологічної освіти. «Необхідність філософії освіти зумовлена статусом освіти - вчити й виховувати (в їхній безперервній взаємодії). Мета будь-якої освітньої системи полягає у формуванні такого практичного світогляду людини, який би щонайкраще поєднував ії професійну діяльність із загальними цивілізаційними цінностями, закладеними в основу цієї системи» [10, 275]. Тому постала необхідність дослідити екологічну освіту у взаємодії 3 екологічним вихованням, яке формує життєво-ціннісні орієнтації сучасної людини.

У літературі зазначається, що екологічне виховання повинно формувати світовідчуття особистості і спрямоване безпосередньо до емоційно-чуттєвого світу. Н.Ф.Тарасенко розширив його завдання: «Екологічне виховання не просто і не тільки спрямоване до чуттєво-духовної сфери людини; воно характеризує перш за все якісні зміни всього комплексу людського буття і світоставлення, акцентує на визначеному вимірі способу людського життя в цілому. Його необхідно розглядати як процес оволодіння людиною практичної діяльності в невід'ємній єдності практики, природи, 
спілкування, знання і наукового світогляду» $[12,242]$. Екологічна освіта має своє завдання і зорієнтована на навчальний процес, на раціональне мислення, на формування світогляду, екологічного знання, принципів, позицій особистості. Тому виховання, як і знання, діалектично поєднуються в процесі освіти, а тому екологічне виховання можна пояснити «як систему цілеспрямованого постійного впливу на свідомість і поведінку об'єкта з метою формування у нього відповідних норм толерантного ставлення до природи» [15, 256-257], саме через освіту відбувається трансформація екологічного знання у виховання, коли відбувається органічне поєднання раціонального утилітарного й нормативно-ціннісного змісту у свідомості людини, в їі ставленні до природи.

Дуже важливо в екологічному вихованні прагнути органічно поєднати раціональний і емоційний аспекти в свідомості людини, в iï ставленні до природи. Здійснене в процесі екологічної освіти таке виховання дозволяє із знанням справи вирішувати проблеми, що виникають у процесі діяльнісного відношення людини до природи, через ековіталістичну розумність, яка орієнтує на ціннісні мотиви в практичній діяльності, дає змогу попереджувати негативні моменти або уникати їх взагалі. При цьому важливо, щоб екологічне виховання сприяло формуванню відповідальності за стан природи перед майбутніми поколіннями, а тому спрямовувало людську діяльність на ліквідацію негативних наслідків відношення до природи.

Необхідно сформувати у спеціаліста знання того, що робити, щоб не відбувалася руйнація природи, а таке прагматичне ставлення, яке ми бачимо на прикладах, відбувається тому, що в процесі освіти не виховували гуманне ставлення, відповідальність за природу. Потрібно навчити спеціаліста мати бажання знаходити засоби оновлення природи й показувати це в кожній конкретній навчальній дисципліні.

У підсумку варто зазначити, що екологічне виховання повинно мати чітку моральну спрямованість. У свою чергу екологічна освіта включає в себе знання про доцільність тієї чи іншої діяльності відносно природи для задоволення потреб людини й суспільства, частіше за все виробничих. У той же час така доцільність діалектично пов'язана із смисложиттєвим цілепокладанням, змістом якого $є$ таке спрямування діяльності відносно природи, щоб не нанести їй шкоди. У процесі екологічної освіти виховується як ставлення до спрямованої на доцільність діяльності, так і до самого екологічного знання. 
Таким чином, розв'язання даної наукової проблеми здійснюється у екологізації сучасної освіти, і як результат - у формуванні життєво-ціннісних орієнтацій людини на засадах гуманізму, відповідальності, ековіталізму з метою здолання екологічної кризи.

Екологічна освіта і iї наукове забезпечення є пріоритетними у концепції сталого розвитку, а відтак iї наступним завданням у формуванні життєво-ціннісних орієнтацій особистості буде прагнення органічного поєднання раціонального й емоційного змісту в свідомості людини, в її ставленні до природи.

Новизна одержаних результатів полягає у обгрунтуванні базової ролі екологічної освіти, яка має бути засадничою в сучасній освіті всіх рівнів, починаючи з екологічної просвіти, у визначенні екологічного виховання як процесу формування такого ставлення до природи, яке вбачало б у ній абсолютну цінність життя й відповідно спрямовувало б поведінку людей як доброчинну саме на основі головної цінності - цінності природи. При цьому життєво-ціннісні орієнтації сучасної людини необхідно доводити до розуміння й бажання зберігати природу в будь-якому процесі людської діяльності. Формування життєво-ціннісних орієнтацій сучасної людини спонукає до оволодіння екологічним знанням, вміння ним користуватися за будь-яких умов і творчо його використовувати при розв'язанні проблеми «людина-природа».

Можна зауважити, що перспективи досліджень у даному напрямку полягатимуть в розкритті екологічної освіти з точки зору взаємодії людини й природи, коли виробнича доцільність зорієнтовується на ціннісно-гуманістичне цілепокладання, коли «мати» перетворюється на «бути». Разом 3 тим гармонізація відносин людини з природою можлива лише за умов засвоєння екологічного знання й особистої відповідальності людини за стан природи і життя в цілому.

\section{ЛІТЕРАТУРА}

1. Андрущенко В.П. Про концептуальні засади філософії освіти України / В.П.Андрущенко, В.С.Лутай // Практична філософія. -2004. -№2. - С.35-44.

2. Берегова Г.Д. Пошуки нових філософсько-освітніх парадигм у контексті освітньої кризи [Електронний ресурс] / Г.Д.Берегова // Культура i сучасність. - 2013. - № 2. - С.3-9. - Режим доступу: http://nbuv.gov.ua/ UJRN/Kis_2013_2_3 
3. Вища освіта як фактор подолання ціннісного розколу в Україні : монографія (рукопис) / авт. кол.: З.Самчук (керівник), Т.Андрущенко, В. Баранівський, О. Бульвінська та ін. - К., 2015. - 377 с.

4. Во имя мира, безопасности и сотрудничества : К итогам совещания по безопасности и сотрудничеству в Европе, состоявшегося в Хельсинки 30 июля - 1 августа 1975 г. - М. : Политиздат, 1975. - 96 с.

5. Гардашук Т. В. Концептуальні параметри екологізму : [монографія] / Тетяна Василівна Гардашук. - К. : Вид. ПАРАПАН, 2005. - 200 с.

6. Гур В. И. Этическая концепция германской социал-демократии (историкофилософский анализ: Бад-Годесберг, 1959 - Берлин, 1989) : [монография] / Виктор Гур. - К. : Центр социальных исследований им. В.Старосольского, 1997. - 256 с. (Серия: Библиотека «Основные ценности»).

7. Кисельов М.М. Національне буття серед екологічних реалій: [Монографія] / М.М. Кисельов, Ф.М.Канак. - К. : Тандем, 2000. - 320с.

8. Кримський С.Б. Запити філософських смислів: [монографія] / Сергій Кримський. - К. : Вид. ПАРАПАН, 2003. - 240 с.

9. Крисаченко В.С. Людина і біосфера: основи екологічної антропології / Валентин Семенович Крисаченко. - К. : Заповіт, 1998. - 688 с.

10. Освітологія: хрестоматія : навч. посібник для студентів вищих навчальних закладів / Укладачі: В.О.Огнев’юк, С.О.Сисоєва. - К. : ВП «Едельвейс», 2013. - $728 \mathrm{c}$.

11. Рябченко B.I. Вища школа України в загальноцивілізаційному контексті: соціально-філософський аналіз з позицій світоглядно-компетентнісного підходу : [монографія] / В.І.Рябченко. - К. : Фітосоціоцентр, 2015. - 674 с.

12. Тарасенко Н. Ф. Природа, технология, культура. Философско-мировоззренческий анализ : [монография] / Николай Тарасенко. - К. : Наукова думка, 1985. $-256 \mathrm{c}$.

13. Чорноштан T.M. Філософсько-етичні засади екологічної освіти : автореф. дис. на здобуття наукового ступеня кандидата філософських наук : спец. 09.00.10 - філософія освіти. - К., 2008. - 19 с. 252

14. Швайцер A. Благоговение перед жизнью / Швайцер А. [Сост. и посл. А.А.Гусейнова; Общ. ред. А.А.Гусейнова и М.Г.Селезнева]. - М. : Прогресс, 1992. - 576 с.

15. Юрченко Л.І. Екологічна культура в контексті екологічної безпеки : [монографія] / Л. І. Юрченко. - К. : ПАРАПАН, 2008. - 296 с.

Анацька Н.В. Життево-иіннісні орієнтациї в системі екологічної освіти Шлях розвитку сучасного суспільства зорієнтований на постійне збільшення виробництва і споживання природних ресурсів, що спричиняє глобальну екологічну кризу. Показано, що формування нового способу взаємин людини, техніки й природи є першочерговим завданням сучасної цивілізації. 
Актуальність також обумовлена і потребою формування життєвоціннісних орієнтацій, зокрема відповідальному й гуманному відношенню як до природи, так і до людини.

В статті розкрито, що саме життєво-ціннісні орієнтації сучасної людини мають сформувати екологічно зорієнтовану діяльність. Ціннісні орієнтації, які становлять внутрішню складову свідомості, а також самосвідомості людини, відіграють значну роль у спрямованості іiі життєво-ціннісних орієнтацій, тому що, орієнтуючи на них свої вчинки, особистість у результаті утверджує своє свідоме ставлення до сущого й належного. Відповідно до цього пізнання, яке $\epsilon$ активністю людського розуму й здатне отримувати науково вивірені етичні та інші знання, повинно пояснити норми морального належного по відношенню до природи, які необхідні сучасному суспільству, де відбуваються якісні зміни глобального характеру.

Зважаючи на це, доведено необхідність принципово нових підходів до екологічної освіти - вона не просто має інформувати про стан речей, а навчати дієвим засобам протидії екологічно-кризовим явищам в усіх сферах життя. Ці питання підпорядковані тому, щоб суспільство стало відповідальним за екологічні наслідки науково-технічного прогресу і щоб надати йому соціально-гуманістичного спрямування і саме через екологічні знання, які трансформуються в процесі освіти в життєво-ціннісні орієнтації.

Ключові слова: природа, екологічна освіта, екологічне знання, екологічне виховання, життєво-ціннісні орієнтації, відповідальність, гуманізм, ековіталізм.

Анаикая Н.В. Жизненно-ценностные ориентации в системе экологического образования

Путь развития современного общества ориентирован на постоянное увеличение производства и потребления природных ресурсов, что вызывает глобальный экологический кризис. Показано, что формирование нового способа взаимоотношений человека, техники и природы является первоочередной задачей современной цивилизации.

Актуальность также обусловлена и необходимостью формирования жизненно-ценностных ориентаций, в частности ответственном и гуманном отношении как к природе, так и к человеку.

В статье раскрыто, что именно жизненно-ценностные ориентации современного человека должны сформировать экологически ориентированную деятельность. Ценностные ориентации, которые представляют внутреннюю составляющую сознания, а также самосознания человека, играют значительную роль в направленности его жизненно-ценностных ориентаций, потому что, ориентируя на них свои поступки, личность в результате утверждает свое сознательное отношение к сущему и должному. Согласно этому познанию, которое является активностью человеческого ума и способно получать научно выверенные этические и другие знания, должно объяснить нормы нравственного должного по отноше- 
нию к природе, которые необходимы современному обществу, где происходят качественные изменения глобального характера.

Ввиду этого доказана необходимость принципиально новых подходов к экологическому образованию - оно не просто должно информировать о состоянии дел, а учить действенным средствам противодействия экологически кризисным явлениям во всех сферах жизни. Эти вопросы подчинены тому, чтобы общество стало ответственным за экологические последствия научно-технического прогресса и чтобы придать ему социально-гуманистическое направление именно из экологического знания, которые трансформируются в процессе образования в жизненно-ценностные ориентации.

Ключевые слова: природа, экологическое образование, экологическое знпание, экологическое воспитание, жизненно-ценностные ориентации, ответственность, гуманизм, эковитализм.

Anatska N. Life and Value Orientations in Ecological Education System.

The development path of the modern society is targeted at constant growth of manufacturing and consumption of natural resources, which causes the global ecological crisis. It is shown that formation of a new way of interrelations of human, technology and the nature are the high-priority task of the contemporary civilization.

The relevancy is also driven by the need of creation of life and value orientations, in particular of responsible and humane treatment of both the nature and human.

The article reveals that it is life and value orientations of modern human which must form ecologically oriented activity. Value orientations, which make an internal component of human's consciousness, as well as self-consciousness, play a significant role in targeting of life and value orientations, because guiding behaviour with them, as a result, a personality establishes conscious attitude to all the existent and proper things. Therefore, the cognition, which is an activity of the human mind and is able to receive scientifically verified ethical and other knowledge, must explain the moral norms in regards to the nature, which are necessary for the modern society, where qualitative changes take place.

In view of this, it has been proved the necessity of principally new approaches to ecological education. It should not only inform about the condition of things, but also teach effective countermeasures against environmental crisis phenomena in all spheres of life. These issues demand the society to become responsible for environmental consequences of scientific and technological progress, and to provide it with social and humanistic direction, and in particular through ecological knowledge, which is transformed into life and value orientations in the educational process.

Key words: nature, ecological education, ecological knowledge, life and value orientations, responsibility, humanism, eco-vitalism. 